\title{
Building adaptive capacity to cope with increasing vulnerability due to climatic change in Africa - A new approach
}

\author{
Steve Twomlow ${ }^{\mathrm{a}, *}$, Francis T. Mugabe ${ }^{\mathrm{b}}$, Moses Mwale ${ }^{\mathrm{c}}$, Robert Delve ${ }^{\mathrm{d}}$, Durton Nanja ${ }^{\mathrm{e}}$, Peter Carberry ${ }^{\mathrm{f}}$, \\ Mark Howden ${ }^{\mathrm{f}}$ \\ a ICRISAT Bulawayo, Matopos Research Station, P.O. Box 776, Bulawayo, Zimbabwe \\ ${ }^{\mathrm{b}}$ Faculty of Natural Resources Management and Agriculture, Midlands State University P Bag 9055, Gweru, Zimbabwe \\ ${ }^{\mathrm{c}}$ Zambia Agricultural Research Institute, Mt. Makulu Central Research Station, P/B 7, Chilanga, Zambia \\ ${ }^{\mathrm{d}}$ TSBF-CIAT, P.O. Box MP228, Harare, Zimbabwe \\ e Zambian Meteorological Department, Lusaka, Zambia \\ ${ }^{\mathrm{f}}$ CSIRO Sustainable Ecosystems, GPO Box 284, Canberra, ACT 2601, Australia
}

\section{A R T I C L E I N F O}

Available online 10 July 2008

\section{Keywords:}

Climate change

Adaptive capacity

Coping strategies

Drought

\begin{abstract}
A B S T R A C T
The world community faces many risks from climate change, with most scenarios indicating higher temperatures and more erratic rainfall in Africa. Predictions for southern Africa suggest a general decrease in total seasonal rainfall, accompanied by more frequent in-season dry spells that will significantly impact crop and livestock production, and hence economic growth in the region. The hardest hit will be the rural poor in the drier areas, where crop failure due to drought is already common and chronic food emergencies afflict the region in most years. Lessons can be learnt on how the rural poor currently cope with the vagaries of climate and these can be used to help them adapt their current production systems to the future threats of further climate change. But this assumes the institutions that work towards the economic empowerment of the rural poor have the requisite skills to understand their current coping strategies and how adaptation can be facilitated. A new initiative led by Midlands State University and the Zambian Meteorological Office proposes that improving the ability of institutions that train the 'Future Change Agents', who will subsequently support smallholder communities in adapting their agricultural practices to current climate variability, is the first step in building adaptive capacity to cope with future climate change. The capacity of African scientists, regional organizations and decision-makers in dealing with the issues of climate change and adaptation will be enhanced on a continuing basis, and the impacts of their agricultural development programs improved.
\end{abstract}

(c) 2008 Elsevier Ltd. All rights reserved.

\section{Introduction}

The greatest development challenge facing our increasingly globalized world is the long-term sustainable development of Africa's rural poor (UN, 2000). Since the year 2000, the energies of development partners worldwide have focused on achieving measurable targets through the time bound (2000-2015) Millennium Development Goals (MDGs). Whilst significant progress has been made towards these goals in the less developed regions of the America's and Asia, the dryland regions of sub-Saharan Africa have not made the same progress (UN, 2005). This is principally because they have not been able to generate sustained economic growth of the type that now characterizes much of Asia. Indeed for much of

\footnotetext{
* Corresponding author.

E-mail addresses: S.Twomlow@cgiar.org, twomlowtravel@yahoo.com (S. Twom-
}

Africa the situation is actually getting worse, as documented in "Our Common Interest," the recent broad constituency report of the Africa Commission (2005).

"African poverty and stagnation is the greatest tragedy of our time. Poverty on such a scale demands a forceful response. And Africa - at country, regional, and continental levels - is creating much stronger foundations for tackling its problems. Recent years have seen improvements in economic growth and in governance. But Africa needs more of both if it is to make serious inroads into poverty. To do that requires a partnership between Africa and the developed world, which takes full account of Africa's diversity and particular circumstances. (Africa Commission, 2005).”

Unfortunately, efforts to develop African economies and achieve the MDGs must contend with the increasing challenge of climate change (see for example, Love et al., 2006; Stern, 2006; UNDP, 
Table 1

Anticipated impacts of climate change in sub-Saharan Africa

- Decreased rainfall, increased temperature and evaporation in dry areas

- Frequent drought spells leading to severe water shortage and increased risk of crop failure

- Change in planting dates of annual crops

- Increased fungal outbreaks and insect infestations due to changes in temperature and humidity

- Decrease in forest area and area under cultivation

- Decline in crop and livestock production

- Increased risk of food shortage and famine

- Reduction in ecosystem integrity and resilience, and decline in biodiversity

- Increased potential of malaria transmission and burden on the country's health care system

- Sea level rise

Various sources such as UNEP, 2003; Cooper et al., 2008; Stern Report; IRI, 2006; UNDP, 2006

2006). Most scientists now agree that global warming is inevitable, (IPCC, 2007), and that it will have major impacts on the climate worldwide and agricultural productivity, particularly in sub-Saharan Africa (Table 1).

In this paper we review the challenges of future climate change on smallholder agriculture in Africa, and what steps are required to build adaptive capacity within the research and development community of southern Africa to help smallholder farmers cope with these future challenges.

\section{The challenges of future climate change in African smallholder agriculture}

The agricultural systems of sub-Saharan Africa are diverse and vast, with water a transient resource in both space and time. Drought is a re-current feature of the southern African agricultural climate both between and increasingly within seasons (Twomlow et al., 2006). In fact, it is increasingly unusual for drought not to occur somewhere in southern Africa each year (UNEP, 2002), and it is universally accepted that climate influences development and must be integrated into the African development agenda (NEPAD, 2002, 2004). Many donor agencies are now conducting 'climate proofing' reviews of overseas development investments to reduce the risk of negative impacts from future climate change on their investments (e.g. IRI, 2006).

Despite this knowledge, and the dependence of southern African economies on rain-fed agriculture, advances in productivity have been patchy and disappointing, given the considerable investment in public agricultural research (Anderson, 1992; Ryan and Spencer, 2001; NEPAD, 2004). Yet, to develop more resilience in economies, requires economic growth, particularly in the agricultural sector. More effective climate risk management adds an important dimension to that agenda, but in no way substitutes for current development efforts (IRI, 2006). The pendulum of international public emotion may be swinging too far to the side of alarmism, though. Fears may cause us to take hasty actions in response to long-term climate change, that divert resources from the steps that are needed to ease the larger impacts on the rural poor in the short to medium term (Table 2). Nevertheless, we also need to recognise that there is a high probability that climate change is already occurring and that past emissions of greenhouse gases have already committed the globe to further warming of around $0.1^{\circ} \mathrm{C}$ per decade for several decades (Solomon et al., 2007), making some level of impacts, and necessary adaptation responses, already unavoidable (Howden et al., 2007) In essence how do we achieve a balance that enables or facilitates adaptation to current climatic risk without jeopardizing the future.

Climate change scenarios generally indicate higher temperatures for most of Africa, although projections for precipitation
Table 2

Adaptation measures most commonly cited in the literature to combat the vagaries of climate

- Increase irrigation area to boost crop production

- Introduction of low water use crops and adoption of sustainable water resource management policies (seasonal rainfall harvest; water quality control)

- Increase capital investment in reservoirs and infrastructure

- Reduction of water loss through water conserving technologies

- Make water resource management an attractive career and field of investment

- Institute policy mechanisms to control unsustainable forest clearing and forest consumption (plans for reforestation and afforestation projects with a primary concentration on Hashab trees)

- Promote techniques for tackling emergency food shortage

- Adjust farming areas and reduce animal population

- Promote use of Liquid Petroleum Gas for cooking and solar cookers instead of inefficient woodstoves and charcoal stoves

Various sources such as UNEP, 2003; Cooper et al., 2008; Love et al., 2006; Stern Report; IRI, 2006; UNDP, 2006.

trends vary from slight increases in West Africa to slight decreases in Southern Africa (Washington et al., 2004; Stige et al., 2006; IPCC, 2007). There is a general consensus about increasing variability of climate, which will lead to an increase in drought (both inter and intra seasonal) and flood events, and more uncertainty about the onset of the rainy seasons. This is likely to impact on the social as well as cultural and economic development of rural poor communities (e.g. Mortimer and Manvel, 2006). The agricultural productivity per unit of water ("crop per drop") in Africa is the lowest worldwide, and is far below its potential (Rosegrant et al., 2002). Yet despite many research initiatives, development co-operations, NGO's and strong efforts by FAO and local governments, sub-Saharan Africa still suffers from food insecurity and undernutrition and the chronic food emergencies that have afflicted Malawi, Mozambique, Zambia and Zimbabwe seem set to become more frequent. It is predicted that yields for staple cereals will fall sharply with a $1-2{ }^{\circ} \mathrm{C}$ change in temperature and more erratic rainfall patterns (Cane et al., 1994; Stige et al., 2006).

\section{Mitigation and adaptation}

Mitigation and adaptation are the two strands to any strategy for tackling the threat posed by climate change (Solomon et al., 2007). Mitigation attempts to minimise future climate change by reducing emissions including through weakening the link between economic growth and carbon emissions. Adaptation includes changes in management activities, institutional settings and infrastructure that enables effective response to the changes in climate that may occur. It needs to acknowledge that some degree of climate change is inevitable and that many of the most threatened countries have the least capacity to adapt. The international response on both fronts has been inadequate-spectacularly so in the case of adaptation (see Table 2), with large sums of money diverted into food relief programs, a short-term coping mechanism that does negates the development of adaptive strategies, and can foster a dependency syndrome (IRI, 2006; IPCC, 2007).

Prevailing lessons that are coming from the poor of sub-Saharan Africa are that they can help us with this task, because they have been there before. Inhabitants of the Drylands have always been adjusting their livelihood strategies to large variations in climate; both short and long-term. Some innovative farmers and communities have improved on traditional practices and developed various coping strategies that enable them to survive extreme climatic events (e.g. Scoones, 1994; Mazzucato and Niemeijer, 2000). By going back and studying the coping strategies of the rural poor (Table 3) with respect to climate, we may find clues that, when combined with leading edge scientific tools such as weather-driven crop simulation models (e.g. Keating et al., 2003), spatial weather 
Table 3

Project definition of coping and adaptive strategies

Coping strategies

Strategies that have evolved over time through peoples' long experience in dealing with the known and understood natural variation that they expect in seasons combined with their specific responses to the season as it unfolds

Adaptive strategies

Longer-term (beyond a single season) strategies that are needed for people to respond to a new set of evolving conditions (biophysical, social and economic) that they have not previously experienced. The extent to which communities are able to successfully respond to a new set of circumstances that they have not experienced before will depend upon their Adaptive Capacity

Adapted from Cooper et al., 2008; Mortimer and Manvel, 2006.

data generators (e.g. Semenov et al., 1998; Jones and Thornton, 2002), and seasonal climate forecasting models (e.g. Meinke et al., 2006) may help scientists and the farmers to explore new opportunities, together in a participatory manner that will enable adaptation of the farming systems.

There is a need to apply options for diversified production systems and diversified livelihood options that can help vulnerable people cope with climate variability, more extreme events, increasing variability of precipitation, and the associated socioeconomic implications of these changes. It is now widely accepted that by focusing on improving the resilience of the current production systems and smallholders' risk management strategies in the shortterm, we can support adaptation to longer-term effects of climate change (McKeon et al., 1993; Mortimer and Manvel, 2006). Therefore, it is key to focus on building resilience so as to enhance adaptive capacity, i.e. "the ability of a system to adjust to ... change... to moderate potential damages, to take advantage of opportunities or to cope with the consequences" (IPCC, 2001, p. 21). There is much uncertainty about how to promote adaptation to climate change among such small scale land-owners. Yet, it is these small scale land-owners who experience the greatest risk from current climate variability and to future climate change (Easterling et al., 2007). Unfortunately, the skills base required for the research and development community workers to do this work in much of Africa is lacking (IRI, 2006; Cooper et al., 2008).

\section{Characterizing and mapping the agricultural implications of climatic variability}

There is clearly a need for the development of robust frameworks which can facilitate and guide risk assessment and management, longer term strategic planning and decision making by all 'investors' involved in rain-fed farming. Increasingly, experience shows how this can be facilitated by the use of long-term daily climatic data combined with field based research results, spatial weather generators, crop growth simulation and soil and water management models, geographic information systems and improved access to and use of climate analysis software. Crops principally respond to daily climate or sequences of daily climate, in particular, daily rainfall becomes the key parameter in rain-fed agriculture. Such records have been collected throughout sub-Saharan Africa for decades, and in this context are now proving to be invaluable. The use of such records allows the determination of the "probability" of occurrence of a wide range of climate parameters of importance to agriculture and hence the risk associated with rain-fed agriculture. Although, as the experience in Malawi this last season showed, with loss (through rotting) of large areas of high value irrigated green maize due to flooding, the problem is not only in rain-fed systems.

At one level of analyses, research can focus on the probability of climatic events of known importance to farmers (and their support agents) such as the start of the growing season, the frequency of dry spells within the season, the frequency of high intensity erosive rainfall events, the impact of prolonged wet spells on plant disease or the length of the growing season itself. Such analyses are becoming increasingly easy to undertake as initiatives are implemented that provide more user-friendly software, and the training to use these capabilities. The outputs of such analyses provide a useful framework for making longer-term strategic choices concerning agricultural practices that are directly influenced by single or a combination of climatic events. They also provide an analysis of the benefits and risks of tactical within-season responses via integration of the impact of variable climate with a range of soil, water and crop management choices. Such simulation models, driven by daily climatic data, can be used to predict the impact of long-term climate variability on the probability of success of a range of crop, water and soil management strategies. The use of such models, with long runs (30 years or more) of daily climatic data thus provides a quick and much less costly opportunity of 'accelerated learning' compared with the more traditional multilocation, multi-seasonal and multi-factorial field trials (e.g. Meinke et al., 2006). One such model that is becoming increasingly used in sub-Saharan Africa is the Agricultural Production Systems Simulator (APSIM; Keating et al., 2003). APSIM can simulate the interaction of climate and crop, soil and water management practices on the growth and yield of a range of crops amongst which maize, sorghum, pearl millet, chickpea, pigeon pea, soybean, groundnut, sunflower, cotton and trees are likely to be of most interest in sub-Saharan Africa. APSIM has been parameterised and validated for most of these crops.

The suitability of APSIM in simulating crops in smallholder farming systems in sub-Saharan Africa has been tested over several years and in a number of regions. Building on the precursor simulation work of Keating et al. (1991) in Kenya, the APSIM model has been tested and used, for example in the analyses of fertilizer recommendations for dry and variable environments (Dimes et al., 1999, 2003; Shamudzarira et al., 1999); in evaluating crop improvement technologies and their impact on water use efficiency (Okwach et al., 1999; Dimes, 2005; Ncube et al., 2008); in assessing the benefits of improving manure quality and combination with inorganic fertilizer (Carberry et al., 1999; Delve and Probert, 2004; Ncube et al., 2007), in evaluating whole farm productivity and trade-offs between investment in labour and fertilizer (Carberry et al., 2004), extrapolation of research findings to other sites (Rose and Adiku, 2001) and in adding value to seasonal climatic forecasting (Rao, pers comm). It is emphasized that useful outputs from APSIM rely upon reliable long-term climatic data, soil description data and experimental data sets to evaluate and validate the model.

A recent, simple and successful example of 'accelerated learning' using APSIM occurred in southern semi-arid Zimbabwe where nitrogen deficiency is widespread in maize and yields are low and variable. Nitrogen fertilizer use is recommended at a rate of $52 \mathrm{~kg} \mathrm{~N} \mathrm{ha}^{-1}$, but is seldom adopted by farmers as it is considered risky and too expensive. Researchers therefore asked farmers how much fertilizer they could afford and would actually be prepared to use under such conditions and were told about $17 \mathrm{~kg} \mathrm{~N} \mathrm{ha}^{-1}$, one third of the recommended rate. Forty six years of daily climatic data from Masvingo, a local meteorological station, were used to simulate maize yields with the application of 0,17 and $52 \mathrm{~kg} \mathrm{~N} \mathrm{ha}^{-1}$. The results of this simulation confirmed farmers' perception of quite variable $\mathrm{N}$-responses (Fig. 1), but also suggested useful responses to $17 \mathrm{~kg} \mathrm{~N} \mathrm{ha}^{-1}$. The outputs of this simulation were then calculated as 'economic rates of return' to fertilizer use and expressed in terms of probability of success (Fig. 2). Except in very bad years, rates of return to the farmer preferred rate of $17 \mathrm{~kg} \mathrm{~N} \mathrm{ha}^{-1}$ were substantially better than the recommended 


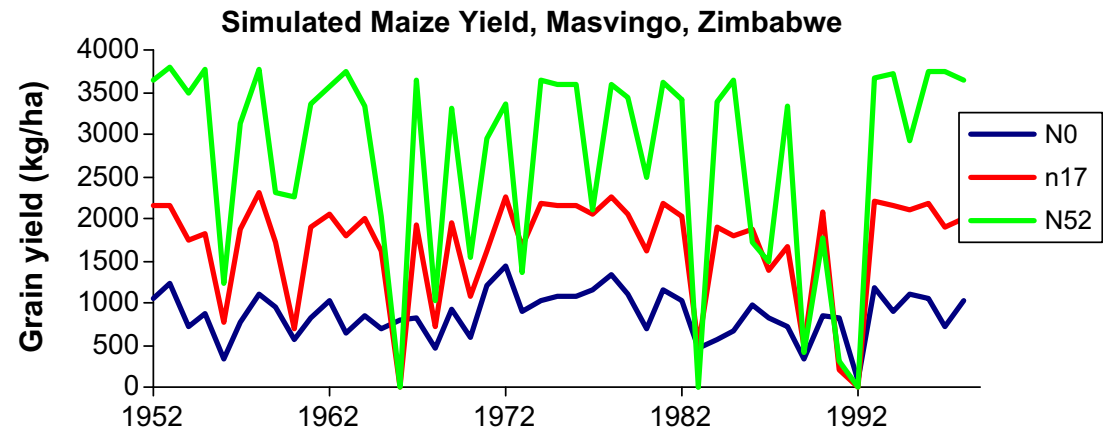

Fig. 1. Predicted (APSIM) response of maize to 0, 17 and $52 \mathrm{~kg} \mathrm{~N}$ ha $^{-1}$ at Masvingo, Zimbabwe. 1952-1998 (Dimes, 2005).

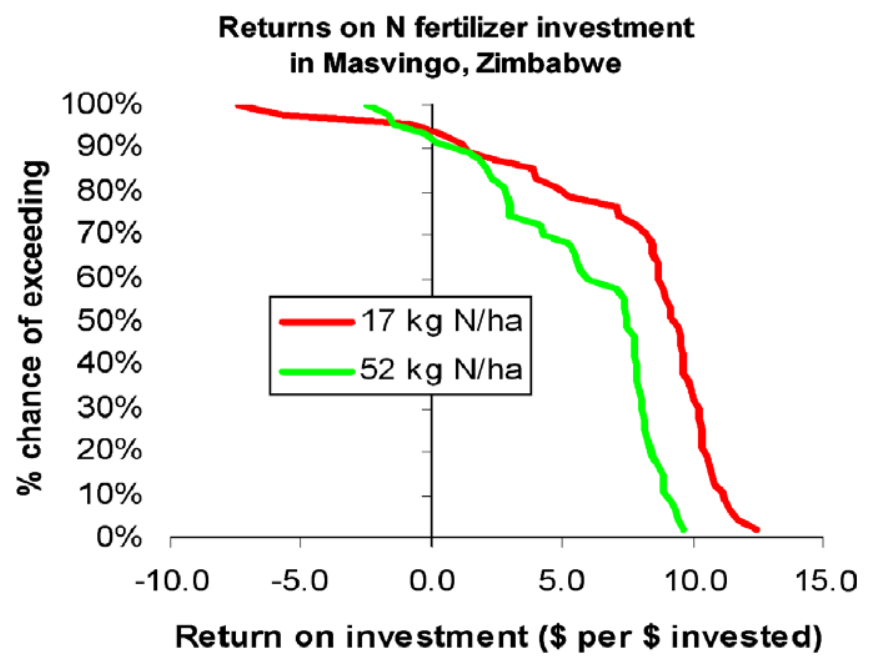

Fig. 2. The \% chance of exceeding given rates of return on $\mathrm{N}$-fertilizer investment on maize production at 17 and $52 \mathrm{~kg} \mathrm{~N} \mathrm{ha}^{-1}$. Masvingo, Zimbabwe (Dimes, 2005).

rate. The outputs of this simulation gave farmers, fertilizer traders, extension staff, Non Government Organization's, donors and researchers the confidence to successfully evaluate this 'microdosing' rate of $\mathrm{N}$ with 160,000 farmers in Zimbabwe in the 2003/ 04 cropping season. Despite poorer than average rains, micro-dosing increased maize grain yields by $30-50 \%$ and almost every farmer achieved significant gains, and more than covered the cost of the investment in fertilizer (Twomlow et al., 2007). In fact, Rohrbach et al. (2005) estimated that the distribution of $25 \mathrm{~kg}$ of ammonium nitrate fertilizer to each of 160,000 farm households contributed 40,000 additional tons of maize production, valued by the World Food Program at 5-7 million USD. Micro-dosing is enabling farmers to adapt their attitude toward, and their practice of, fertilizer use as well as allowing their support agents to adapt their fertilizer recommendations and distribution strategies. The initiative is ongoing and expanding to include conservation agriculture principles (Mazvimavi et al., 2007).

It is clear that simulation modelling can be invaluable in posing a wide range of 'what if' questions which mirror those asked by farmers and can provide valuable insights and answers framed in the context of the long term characteristics of climate variability in any given location. In other words, they can contribute directly to enhanced and more resilient coping and adaptive strategies. Indeed, recent village-based experience in Zimbabwe has shown that providing 'on the spot' answers to farmers' climate risk management questions through the use of lap-top computers and simulation models aroused enormous interest amongst farmer groups and has great potential (Carberry et al., 2004; Whitbread et al., 2004).

The value of the type of research described above is, however, constrained to some extent by the fact that it relies upon 'point source' climate data collected at specific weather stations, thus making interpolation of the outputs between weather stations problematic, and skilled research and development workers. The latter can be overcome by the use of modern and proven spatial weather generators such as MarkSim (Jones et al., 2002), that have already been used in Kenya as a risk mapping aid for farmer field schools in the drier areas (Farrow, 2005). A typical simulation output is presented in Fig. 3. The former requires future investments to build capacity.

The combined use of crop growth simulation models, historic climatic data sets and weather generators, such as, MarkSim is a powerful combination that allows both the characterization and the subsequent mapping of the agricultural implications of climatic variability (Jones and Thornton, 2002). It is also possible to integrate different climate change scenarios into MarkSim and, through crop growth simulation models, assess their impact on agricultural production and poverty spatially (Jones and Thornton, 2003; Thornton et al., 2006). However, it should be noted that the outputs from these stochastic models are not direct substitutes for historical data, which can be linked to climate drivers such as the El Niño Southern Oscillation phenomenon (ENSO), providing the opportunity for tactical management changes (coping/adaptation) in response to seasonal or other climate predictors.

\section{Integrating climate risk management approaches to address stakeholder concerns}

With the increasing availability, reliability and ease of use of such tools as described above, it now becomes possible for decision-makers and investors involved in agriculture to formulate a development agenda that integrates the following three key aspects of climate risk management, namely:

1. Decision-support frameworks that provide a longer-term strategic understanding of the temporal and spatial distribution of climatic variability and its impact on the probability of performance and profitability of existing and innovative agricultural practices.

2. Seasonal climate and agricultural forecasting to enable farmers and other stakeholders to 'fine tune' long-term strategies in the context of the approaching season and thus to plan tactically and farm more effectively in the context of variable weather.

3. Information on the extent to which climate change is impacting, or is likely to impact, on the nature of climate variability and the implications for rain-fed farming systems and their future development and productivity. 


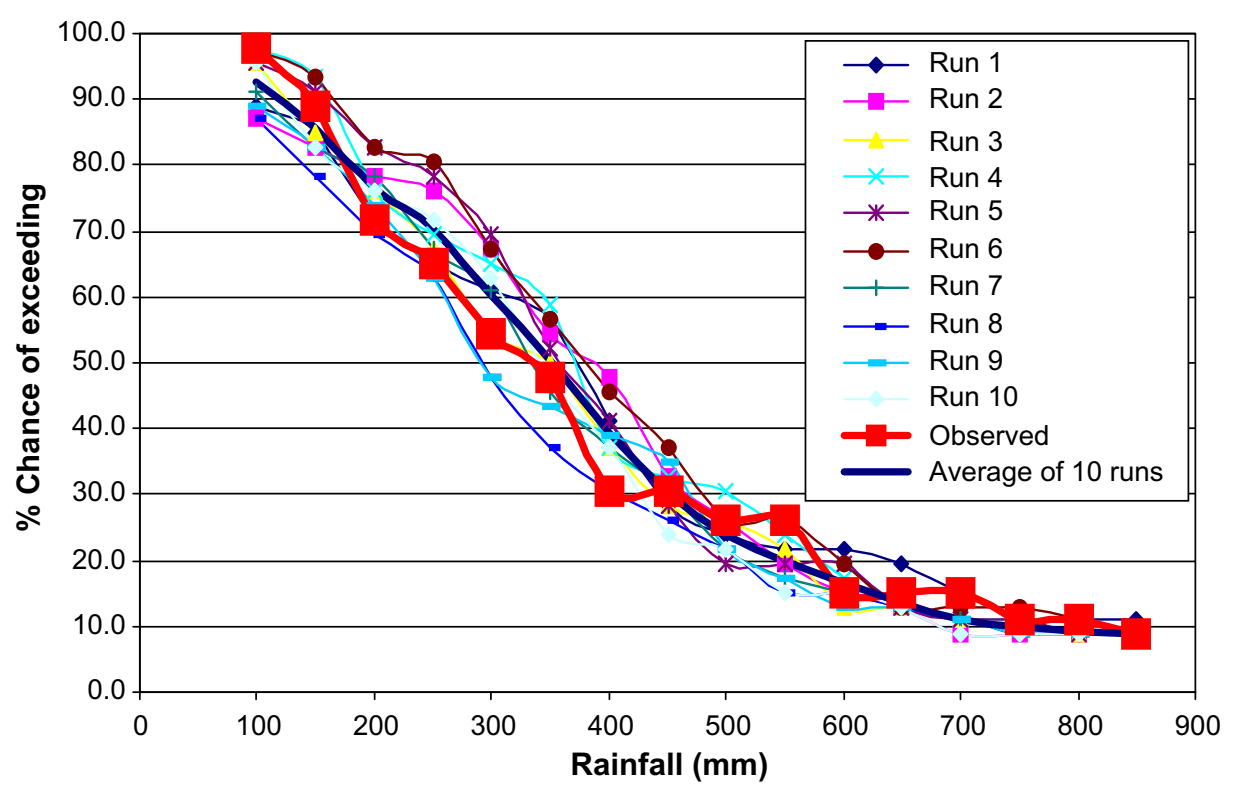

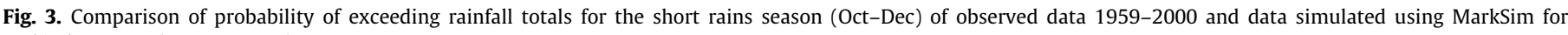
Makindu, Kenya (Farrow, 2005).

The demand for integrated climate risk management strategies is increasingly being voiced by a broad range of investor stakeholders who are seeking to identify appropriate short and longer-term investment strategies, for example:

- National and district policy makers who are charged with making short and longer-term agricultural investment decisions on the types of development initiatives to promote and support in any given season and area.

- The private sector and micro-finance Institutions needing a clear picture of season to season variability in production and its implications for the establishment and sustainability of viable market enterprises and financing schemes.

- Extension services and development Non Government Organization's working with farmers who want to better target and test innovations that have been shown to have a long-term acceptable level of probability of success and who would wish to advise their clients which innovations are likely to be most appropriate in the coming season.

- Farmers and farmer groups who want information on the likely performance of an innovation in good, average or poor years before singly or jointly making short-term or long-term investment in such an innovation.

- Disaster relief agencies and national policy makers who want to have due warning of impending food shortages in any given season coupled with a longer-term temporal and spatial perspective on the probability of such shortages and appropriate postdisaster recovery strategies.

- National and regional meteorological services who are increasingly seeking opportunities to use their information and skills in the agricultural development arena.

In many of the recent plethora of meetings and internationally commissioned reports on managing and adapting to the future vagaries of climate change, greater emphasis is placed on enabling rural communities to adapt, the institutional support required and raising awareness of the issues. Yet few give due cognizance to the need to build capacity within Africa's national research and extension systems to achieve the former (e.g. IRI, 2006; Stern, 2006; UNDP, 2006; COP 12; Cooper et al., 2008).
Such capacity building is a pre-requisite to understanding smallholder farmers' current coping strategies and assisting them to develop adaptation strategies. The exceptions include the recently published GAP analyses commissioned by DFID (IRI, 2006), The World Bank Institute Science Policy Forum on Adaptation to Climate Change in Africa (World Bank, 2006) and recent articles by Easterling et al. (2007); Howden et al. (2007) and Mortimer and Manvel (2006).

All the above reports highlight the need for decision support at the household and Institutional levels but, fail to give strong enough recognition to the following questions, which need to be addressed if we are to improve the adaptive capacity of the smallholder African farmer:

- Do we have the technical capacity within Africa's research and development community to support these initiatives?

- The demands for new skills for research and development professionals in conducting integrated agriculture research for development and, how do we institutionalize them?

In fact, there appears to be a certain amount of misplaced zeal and a lack of understanding within some of the climate change community, as observed at the 2006 COP12 meeting which clearly highlighted the differences between a more theoretical approach, and a practical outcomes-orientated approach (Table 4).

To redress this misplaced zeal it is essential that initiatives are put in place throughout Africa that focus on improving the ability of institutions that train the 'Future Change Agents', who will support smallholder communities in adapting their agricultural practices to current climate variability, is the first step in building adaptive capacity to cope with future climate change. Many of the government and donor supported protracted relief programs will benefit from such initiative, as the capacity of staff in government and non government organizations to understand the implications of climatic variability will be enhanced.

A pilot initiative in Zambia and Zimbabwe was launched in 2007 with funding from Canada's International Development Research Centre's (IDRC) Climatic Change and Adaptation in Africa (CCAA) initiative. 
Table 4

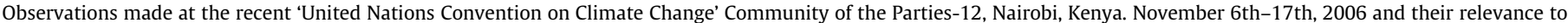
this project - theory versus Pragmatism

1. A great awareness amongst a wide range of well meaning institutions of the potential importance of climate change and of the large amounts of funding that is likely to be available to support R\&D work in this arena. Accompanied by the enthusiasm that inevitably goes with that combination, there appears to be an apparent high level of misplaced activity and a fair degree of lack of knowledge e.g.

- Few people understand the differences between 'weather' and 'climate'.

- An inability to articulate the difference between farmers "coping strategies" and potential farmers "adaptation strategies". These two well defined terms are being used interchangeably by many and this leads to some confusion. The definitions are summarized in Table 3.

2. Similar confusion lay with lack of understanding with regard to dealing with long-term historical climate variability and dealing with future climate change.

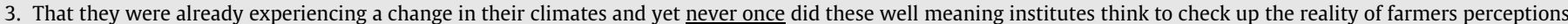
against the hard data of long-term daily climate data. Such triangulation of data has long been recognized by the agricultural participatory research community (e.g. Defoer and Budelman, 2000). Many times the changes farmers are observing in the performance of their rain-fed farms are NOT due to changes in climate but some other factor. Unless projects verify farmers' perceptions, they could well be headed in the wrong direction from the outset. This is an important area in which this project will make a big contribution with a few case studies of situations where farmers are telling us that their climate has changed. They may well be right, but they may not. We can show which the case is.

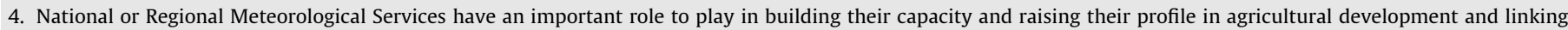
them to agriculture research, development and extension agencies.

Anonymous source.

\section{An initiative to build adaptive capacity in Zambia and Zimbabwe}

Both Zambia and Zimbabwe, target countries for this initiative, are signatories of the United Nations Conventions on Climate and Desertification, as both countries suffer from the adverse affects of climate, that leads to poor and even negative growth in the agricultural sector, and subsequent degradation of the environment as rural households try and meet their livelihood needs. Drought relief is a common feature, almost every year, in the drier areas of both countries, as there appears to be an increasing trend towards a late start to the rainy season, prolonged mid-season droughts, and shorter growing seasons (Cooper et al., 2007; Love et al., 2006). Both countries are actively trying to address these problems, and mitigate the worst effects of climatic variability through breeding more drought tolerant short season crops, and the promotion of improved crop management practices such as precision application of available soil fertility amendments, conservation agriculture, and better weed control (Ncube et al., 2007; Twomlow et al., 2007; Zingore et al., 2008). Both countries support the Southern African Development Community (SADC) Regional Drought Monitoring Centre, based in Harare, Zimbabwe, and receive updates on rainfall and the potential impacts on seasonal agricultural productivity on smallholder subsistence farmers for policy decision making purposes.

The pilot initiative hopes to provide some answers to the following questions:

- What competencies need to be developed in district and provincial planners for provision of improved early warning messages?

- How can an extension dissemination strategy be implemented for relaying messages to farmers on climate forecasting, based on previous experiences?

- What information and technical support do farmers need to improve their decision making to continually build their assets?

- What support do farmers need to adopt knowledge intensive systems for improved food security, increased income and sustainable natural resource management?

- Develop education, research and extension competencies to be able to develop strategies to facilitate rural communities to increase their adaptive capacity to cope with risks and opportunities associated with climate change and variability.

- How can participatory research approaches and decision support tools, using systems simulation modelling and optimisation models, be integrated to develop improved productivity management options with farmers?
- Can existing decision support tools be used to; (i) investigate the benefits and impacts of changing production enterprises (ii) investigate how to optimally manage new enterprises e.g. when to plant, how to fertilise with manures (iii) explore the riskiness of new enterprises using long-term weather data and (iv) conduct sensitivity analyses and determine implications of changes in macroeconomic and other applied policies?

This pilot initiative brings together experiences from national and international research and extension institutions that are working in Zimbabwe and Zambia, to build upon their existing skills, networks and field activities to strengthen regional capacities in linking simulation models, participatory on-farm research and climatic forecasting to increase the competencies of smallholder farmers in coping with current climatic variability and adapting to potential climatic change. Quantification of improvements in household food security, incomes and reduce environmental degradation through the further extensification of production systems are key indicators of this work.

The initiative will also seek to improve incentives and opportunities for households to cope with and adapt to the increasing vagaries of climate by investing in improved crop production practices (inorganic fertilizers, conservation agriculture, alternative crops, such as, forages for livestock) of more practical value to diverse groups of small-scale farmers. These new or adapted technology interventions will improve their returns to investment and give them more flexibility in their within season decision making, so that their crop/livestock management can reflect the prevailing, and predicted, climatic conditions during the season. The initiative will stimulate the adoption of these options by linking their dissemination with complementary investments in climate forecasting, and building linkages to other projects that have either a humanitarian relief focus, or are involved in the development of input and product markets. The linkage of public investments in technology design with private investments in market development will improve the sustainability of these efforts.

\section{References}

Africa Commission, 2005. Our Common Interest. Report of the Commission for Africa. UK Government, London.

Anderson, J.R., 1992. Difficulties in African agricultural systems enhancement? Ten hypotheses. Agricultural System 38, 387-409.

Cane, M.A., Eshel, G., Buckland, R.W., 1994. Forecasting Zimbabwean maize yield using eastern equatorial Pacific seas surface temperatures. Nature 370, 204205.

Carberry, P., Gladwin, C., Twomlow, S., 2004. Linking simulation modeling to participatory research in smallholder farming systems. In: Delve, R.J., Probert, 
M.E. (Eds.), Modeling Nutrient Management in Tropical Cropping Systems, ACIAR Proceedings No. 114

Carberry, P.S., Probert, M.E., Dimes, J.P., Keating, B.A., McCown, R.L., 1999. Role of modelling in improving nutrient efficiency in cropping systems. In: Food Security in Nutrient-Stressed Environments: Exploiting Plants' Genetic Capabilities, ICRISAT, September 1999.

Cooper, P.J.M., Dimes, J., Rao, K.P.C., Shiferaw, B., Twomlow, S., 2008. Coping with better with current climatic variability in the rain-fed farming systems of subSaharan Africa: a dress rehearsal for adapting to future climate change agriculture. Ecosystems and Environment 126, 24-35.

Cooper, P., Singh, P., Traore, P.C.S., Dimes, J., Rao, K.P.C, Gerard, B., Alumira, J., Shiferaw, B., Twomlow, S., 2007. New Tools, Methods and Approaches in Natural Resource Management. ICRISAT, Patancheru 502 324, Andhra Pradesh, India, 68pp.

Defoer, T., Budelman, A., 2000. Managing Soil Fertility in the Tropics. A Resource Guide for Participatory Learning and Action Research. Royal Tropical Institute, Amsterdam, The Netherlands.

Delve, R.J., Probert, M.E. (Eds.), 2004. Modeling Nutrient Management in Tropical Cropping Systems, ACIAR Proceedings No. 114.

Dimes, J.P., 2005. Application of APSIM to evaluate crop improvement technologies for enhanced water use efficiency in Zimbabwe's SAT. In: Pala, M., Beukes, D.J., Dimes, J.P., Myers, R.J.K. (Eds.), Management for Improved Water Use Efficiency in the Dry Areas of Africa and West Asia: Proceedings of a Workshop Organized by the Optimizing Soils Water Use (OSWU) Consortium, April 2002, ICRISAT, Ankara, Turkey, Aleppo Syria; ICARDA and Patancheru, India, p. 288.

Dimes, J.P., Nguluu S., Devi G., Robertson M., Huth N., McCown, R.L., 1999. Simulation of on-farm fertility experiments conducted in 1996 short rains. In: Okwach, G.E., Siambi, M.M. (Eds.), Agricultural Resource Management for Sustainable Cropping in Semi-Arid Eastern Kenya. Proceedings of the First Review Workshop of the CARMASAK Project, 27-29 May, 1997, Machakos, Kenya, CARMASAK Proceedings No. 1, pp. 104-140.

Dimes, J., Twomlow, S., Carberry, P., 2003. Application of new tools: exploring the synergies between simulation models and participatory research in smallholder farming systems. Global Theme 3: Water, Soil and Agrodiversity Management for Ecosystem Resilience. Report no. 5. ICRISAT, P.O. Box 776, Bulawayo, Zimbabwe: and Australia, P.O. Box 102, Toowoomba, Queensland 4350: CSIRO Sustainable Ecosystems/APSRU, 20pp.

Easterling, W., Aggarwal, P., Batima, P., Brander, K., Erda, L., Howden, M., Kirilenko, A., Morton, J., Soussana, J.-F., Schmidhuber, J., Tubiello, F., 2007. Food, fibre and forestry. In: Parry, M.L., Canziani, O.F., Palutikof, J.P., van der Linden, P.J., Hanson, C.E. (Eds.), Climate Change 2007: Impacts, Adaptation and Vulnerability. Cambridge University Press, Cambridge, UK, pp. 73-313.

Farrow, A., 2005. Climatic data and tools for risk mapping as an aid to FAO Farmer Field Schools in the semi-arid areas of Kenya. Working Week Report, CIAT, Kawanda, Kampala, Uganda, 28 November-2 December, 2005.

Howden, S.M., Soussana, J.F., Tubiello, F.N., Chhetri, N., Dunlop, M., Meinke, H., 2007. Adapting agriculture to climate change. Proceedings of the National Academy of Sciences 104, 19691-19696.

IPCC, 2001. Intergovernmental panel on climate change. Climate Change 2001: The Scientific Basis. Contribution of the Working Group 1 to the Third Assessment Report of the IPCC. Cambridge University Press, Cambridge. <www.grida.no/ climate/ipcc_tar/wg1/index.htm>.

IPCC, 2007. Climate Change 2007: Impacts, Adaptations and Vulnerbaility Contribution of Working Group II to the IPCC Fourth Assessment. Cambridge University Press, Cambridge. <http://www.ipcc.ch/>.

IRI, 2006. A Gap Analysis for the Implementation of the 'The Global Climate Observing System Programme in Africa'. The International Research Institute for Climate and Society (IRI) in collaboration with Global Climate Observing System (GCOS), United Kingdom's Department for International Development (DFID), and UN Economic Commission for Africa (ECA), IRI Technical Report Number IRI-TR/06/1, p. 47.

Jones, P.G., Thornton, P.K., 2002. Spatial modeling of risk in natural resource management. Conservation Ecology 5(2), 27. [Online]. <http:// www.consecol.org/vol5/iss2/art27>.

Jones, P.G., Thornton, P.K., 2003. The potential impacts of climate change on maize production in Africa and Latin America in 2055. Global Environmental Change 13 (1), 51-59.

Jones, P.G., Thornton, P.K., Diaz, W., Wilkens, P.W., 2002. Marksim: a computer tool that generates simulated weather data for crop modeling and risk assessment: version 1 . CIAT, 87pp.

Keating, B.A., Carberry, P.S., Hammer, G.L., Probert, M.E., Robertson, M.J., Holzworth, D., Huth, N.I., Hargreaves, J.N.G., Meinke, H., Hochman, Z., McLean, G., Verburg K., Snow, V., Dimes, J.P., Silburn, M., Wang, E., Brown, S., Bristow, K.L., Asseng, S., Chapman, S., McCown, R.L., Freebairn, D.M., Smith, C.J., 2003. An overview of APSIM, a model designed for farming systems simulation. European Journal of Agronomy 18 (3), 267-288.

Keating, B.A., Godwin, D.C., Watiki, J.M., 1991. Optimising nitrogen inputs in response to climatic risk. In: Muchow, R.C., Bellamy, J.A. (Eds.), Climatic Risk in Crop Production: Models and Management in the Semiarid Tropics and Subtropics. CAB International, Wallingford. pp. 329-358.

Love, D., Twomlow, S., Mupangwa, W., van der Zaag, P., Gumbo, B., Nyabeze, W., 2006. Implementing the millennium development food security goals challenges of the southern African context. Physics and Chemistry of the Earth 31, 731-737.

Mazvimavi, K., Twomlow, S., Murendo, C., Musitini, T., 2007. Science in agricultural relief and development programs: The case of conservation farming in
Zimbabwe. In: 26th Conference of the International Association of Agricultural Economists, Accra, Ghana, August 2007.

Mazzucato, M., Niemeijer, D., 2000. Rethinking Soil and Water Conservation in a Changing Society: A Case Study from Burkina Faso Tropical Resource Management Papers 32. Wageningen University and Research Centre, The Netherlands. 378 pp.

McKeon, G.M., Howden, S.M., Abel, N.O.J., King, J.M., 1993. Climate change: adapting tropical and subtropical grasslands. In: Proceedings of the XVII International Grasslands Congress, Palmerston North, New Zealand, pp. 11811190.

Meinke, H., Nelson, R., Kokic, P., Stone, R., Selvaraju, R., Baethgen, W., 2006 Actionable climate knowledge: from analysis to synthesis. Climate Research 33 , 101-110.

Mortimer, M., Manvel, C., 2006. Climate change: enhancing adaptive capacity Natural Resources Systems Program Briefing Note. <www.nrsp.org.uk>, p. 8.

NEPAD, 2002. Comprehensive Africa Agriculture Development Program. New Partnership for Africa's Development, Johannesburg.

NEPAD, 2004. Implementing the Comprehensive Africa Agriculture Development Program and restoring Food Security in Africa. New Partnership for Africa's Development.

Ncube, B., Dimes, J., Twomlow, S., Mupangwa, W., Giller, K., 2007. Raising the productivity of smallholder farms under semi-arid conditions by use of small doses of manure and nitrogen: a case of participatory research. Nutrient Cycling in Agro-ecosystems 77, 53-67.

Ncube, B., Dimes, J., van Wijk, M., Twomlow., S., Giller, K., in press. Productivity and residual benefits of grain legumes to sorghum (Sorghum bicolor (L.) Moench) under semi-arid conditions in southern Zimbabwe: unravelling the effects of water and nitrogen. Field Crops Research.

Okwach, G.E., Huth, N., Simiyu, C.S., 1999. Modeling surface runoff and soil erosion in semi-arid eastern Kenya. In: Okwach, G.E. Siambi, M.M. (Eds.), Agricultural Resource Management for Sustainable Cropping in Semi-Arid Eastern Kenya Proceedings of the First Review Workshop of the CARMASAK Project, 1997, Machakos, Kenya, CARMASAK Proceedings No. 1, 27-29 May, pp. 104140.

Rohrbach, D., Mashingaidze, A.B., Mudhara, M., 2005. Distribution of Relief Seed and Fertilizer in Zimbabwe: Lessons from the 2003/04 Season. ICRISAT and FAO, Bulawayo, Zimbabwe.

Rose, C.W., Adiku, S., 2001. Conceptual methodologies in agro-environmental systems. Soil and Tillage Research 58, 141-149.

Rosegrant, M.W., Cai, X., Cline, S.A., 2002. The role of rain-fed agriculture in the future of global food production. IFPRI, Environment and Production Technology Division Discussion Paper No. 90, February 2002.

Ryan, J.G., Spencer, D.C., 2001. Future challenges and opportunities for agricultural R\&D in the semi-arid tropics. Patencheru, A.P. 502 324, International Crops Research Institute for the Semi-Arid Tropics, India, 83 pp, ISBN 92-9066-439-8 Order code IBE 062.

Scoones, I. (Ed.), 1994. Living with Uncertainty: New Directions in Pastoral Development in Africa. Intermediate Technology Publications, London, UK.

Semenov, M.A., Brooks, R.J., Barrow, E.M., Richardson, C.W., 1998. Comparison of the WGEN and LARS-WG stochastic weather generators for diverse climates. Climate Research 10, 95-107.

Stern, N., 2006. The Economics of Climate Change, Final Report. Sir Nicholas Stern. <http://www.hm-treasury.gov.uk/independent_reviews/ stern_review_economics_climate_change/stern_review_report.cfm> (downloaded 1/12/2006).

Shamudzarira, Z., Robertson, M.J., Mushayi, P.T., Keating, B.A., Waddington, S. Chiduza, C., Grace, P. 1999. Simulating N fertilizer response in low-input farming systems. 1. Fertilizer recovery and crop response. ESA Symposium on "Modeling Cropping Systems", Spain, June 1999.

Solomon, S., Qin, D., Manning, M., Chen, Z., Marquis, M., Avery, K.B., Tignor, M., Miller, H.L., 2007. Climate Change 2007: The Physical Science Basis. Cambridge University Press, Cambridge, UK. 996 pp.

Stige, L.C., Stave, J., Chan, K., Ciannelli, L., Pettorelli, N., Glantz, M., Herren, H.R. Stenseth, N.C., 2006. The effect of climate variation on agro-pastoral production in Africa. PNAS. February 28, 2006. vol. 103 no. 9, 3049-3053 <http:// www.pnas.org_cgi_doi_10.1073_pnas.0600057103>.

Thornton, P.K., Jones, P.G., Owiyo, T.M., Kruska, R.L., Herrero, M., Kristjanson, P. Notenbaert, A., Bekele, N., Omolo, A., 2006. Mapping Climate Vulnerability and Poverty in Africa. International Livestock Research Institute, Nairobi, Kenya.

Twomlow, S., Rohrbach, D., Rusike, J., Mupangwa, W., Dimes, J., NCUBE, B., 2007. Spreading the word on fertilizer in Zimbabwe. In: Mapiki, A., Nhira, C. (Eds.) Land and Water Management for Sustainable Agriculture. Proceedings of the EU/SADC Land and Water Management Applied Research and Training Programme's Inaugural Scientific Symposium, Malawi Institute Management Lilongwe, Malawi, 14-16 February 2006, Paper 6.21 (Chapter 19).

Twomlow, S.J., Steyn, J.T., du Preez, C.C., 2006. Dryland farming in southern Africa. In: Dryland Agriculture, second ed. Agronomy Monograph No. 23. American Society of Agronomy, Madison, Wisconsin, pp. 769-836.

UN, 2000. United Nations Millennium Declaration. United Nations General Assembly, New York.

UN, 2005. The Millennium Development Goals Report 2005. United Nations, New York.

UNDP, 2006. Human Development Report, 2006. Beyond Scarcity: Power, Poverty and the Global Water Crisis. United Nations Development Program, New York.

UNEP, 2002. Global Environment Outlook 3: Past, present and future perspectives. United Nations Environment Programme, Nairobi, Kenya. 
UNEP, 2003. Action Plan of the Environment Initiative of the New Partnership For Africa's Development (NEPAD). United Nations Environmental Program, Nairobi, Kenya.

Washington, R., Harrison, M., Conway, D., 2004. African Climate Report. Report commissioned by the UK Government to review African climate science, policy and options for action. <www.defra.gov.uk/environment/climatechange/ ccafrica-study/index.htm>.

Whitbread, A., Braun, A., Alumira, J., Rusike, J., 2004. Using the agricultura simulation model APSIM with smallholder farmers in Zimbabwe to improve farming practices. In: Whitbread, A., Pengelly, B.C. (Eds.), Tropical Legumes for
Sustainable Farming Systems in Southern Africa and Australia. ACIAR Proceedings, No. 115, Australian Centre for International Agricultural Research, Canberra, Reprint No. 5035, pp. 171-80

World Bank, 2006. Science Policy Forum on Adaptation to Climate Change in Africa Nairobi, Kenya, October 2006. <http://www.iied org/CC/COP12.html>.

Zingore, S., Murwira, H.K., Delve, R., Giller, K.E., 2008. Variable grain legume yields, responses to phosphorus and rotational effects on maize across soil fertility gradients on African smallholder farms. Nutrient Cycling in Agro-ecosystems 80 (1). doi:10.1007/s10705-007-9117-3. 